\title{
Law's power to safeguard global health: a Lancet-0'Neill Institute, Georgetown University Commission on Global Health and the Law
}

Lawrence O. Gostin

Georgetown University Law Center, gostin@law.georgetown.edu

John T. Monahan

Georgetown University Law Center

Mary C. DeBartolo

Georgetown University Law Center

Richard Horton

The Lancet

This paper can be downloaded free of charge from:

https://scholarship.law.georgetown.edu/facpub/1479

http://ssrn.com/abstract=2602237

385 The Lancet 1603-1604 (2015)

This open-access article is brought to you by the Georgetown Law Library. Posted with permission of the author. Follow this and additional works at: https://scholarship.law.georgetown.edu/facpub

Part of the Health Law and Policy Commons, Health Policy Commons, International Law Commons, International Public Health Commons, and the Public Policy Commons 


\section{Law's power to safeguard global health: a Lancet-0'Neill Institute, Georgetown University Commission on Global Health and the Law}

Law at the international, national, and subnational levels has been an effective, although often underappreciated, way to safeguard and promote global health. By law we mean the statutes and regulations that express public policy as well as public institutions, including courts, legislatures, and agencies responsible for creating, implementing, and interpreting the law. Law has a fundamental, yet underused and underdeveloped, role in providing solutions to global health challenges. We are, therefore, launching a Lancet-O'Neill Institute, Georgetown University Commission on Global Health and the Law to examine the vital role of law in responding to major global health challenges.

Global health is influenced by law developed at different levels of government, through various legal tools and diverse legal subjects (panel). Critically, national and international laws relevant to global health are deeply intertwined, creating norms that can be mutually reinforcing. Simultaneously, it is vital to understand the influence of many legal spheres beyond the province of the health sector, including law which relates to agriculture and food, trade and intellectual property, domesticated and wild animals, refugees and humanitarian concerns, and climate change. The interaction between national, subnational, and international law, together with the influence of many legal spheres, illustrate the power-and the weakness-of law as a tool.

Recent events show the value and challenges of using law to address global health events. For example, the 2005 International Health Regulations (IHR) ${ }^{1}$ is the governing instrument for providing a global public health response to the international spread of disease. On Aug 8, 2014, WHO's Director-General declared the west Africa Ebola epidemic a public health emergency of international concern and issued temporary recommendations for actions to reduce the international spread of Ebola and avoid unnecessary interference with international traffic. ${ }^{2}$ Simultaneously, countries exercised their legal powers-for good and for bad-including quarantines and travel restrictions. ${ }^{3}$ The importance of binding hard international law on global health is shown by such agreements as WHO's Framework Convention on Tobacco Control (FCTC). Most states have changed their tobacco control laws to conform more closely to FCTC norms. ${ }^{4}$ At the same time, important disputes over tobacco control are now being heard at the World Trade Organization and in Investment Arbitration proceedings. ${ }^{5,6}$ Conflicts in health, trade, and investment law are powerful illustrations of the international community's challenge when implementing intertwining legal norms across many sectors.

The internationally promoted concept of universal health coverage (UHC) will have to be implemented through national laws, including features such as access, equity, cost, and quality. The statutes and regulations that create UHC programmes may draw upon the human rights lens of equity, crucial to a fair and just vision of the right to health. Further, these statutes and regulations

Panel: Interacting legal influences on global health

Level of government

International: WHO, WTO, OHCHR, FAO, OIE, WIPO

Regional: African Union, European Union, Organization of American States

National: China, South Africa, India, Germany, USA

Subnational: Uttar Pradesh, Baden-Württemberg, London

\section{Legal instruments}

Treaties, global strategies, and codes of practice; constitutions; statutes, regulations, and court decisions; policies, plans of actions, and frameworks

\section{Legal subjects}

Infectious diseases: screen for the presence of disease, trace contacts, and isolate or quarantine people exposed or infected

Injury prevention: occupational health and safety, road safety, consumer safety Food and drugs: ensure safe and effective pharmaceuticals, vaccines, and medical devices Non-communicable diseases: create environments conducive to healthy eating, physical activity, tobacco and alcohol control

Human rights: advancing socioeconomic rights, including to life, to health, and to a safe environment

Trade and investment: impact of trade and investment agreements on domestic regulatory autonomy

Environment: human impacts of climate change

Intellectual property: application of patent laws on affordable access to pharmaceuticals

WTO=World Trade Organization. OHCHR=Office of the High Commissioner for Human Rights. FAO=Food and Agricultura Organization of the United Nations. OIE=World Organisation for Animal Health. WIPO=World Intellectual Property Organization. 
are vital for defining the means by which individuals access health-care services and for supporting strong, resilient, and integrated health systems, which are key factors in controlling outbreaks and protecting global health security.

The O'Neill Institute for National and Global Health Law at Georgetown University in Washington, DC, USA, and The Lancet are launching a high-level Commission to define and systematically describe the current landscape of law that affects global health and safety. Its Commissioners will make the case for the power of law to improve health while revealing current opportunities and challenges under the status quo.

The Commission will concern itself with the complex interaction between laws that have an effect on health at the national, regional, and international levels. The goals of the Commission are to: (1) identify evidence-based means by which law can contribute to improved health and safety outcomes; (2) enhance the ways in which health and safety are prioritised in law and policy; and (3) examine how international organisations, governing processes, and instruments can support, reinforce, and incentivise countries' development of domestic laws to improve their public's health and safety.

The Commission will build on existing scholarship, previous Lancet Commissions, as well as ongoing law reform and international disputes. Commissioners have been chosen from disciplines that range from health, policy, and law to economics and governance. Importantly, the Commission will reflect diverse geographical backgrounds and many sectors, such as international organisations, governments, academia, and civil society. The work of the Commission is expected to last some 18 months.

The Commission will make recommendations on the role of law in establishing overarching normative guidance on global health, including encouraging countries and international bodies to adopt laws that have had a positive effect on health outcomes. Overall the Commission aims to present a compelling argument as to why law should be viewed as a major determinant of health and safety and how the law can be used as a powerful and innovative way to address important global health concerns. The power of law is not simply to create a rule of law, but more fundamentally to achieve the aspiration of a world that can enjoy the highest attainable standard of health.

\section{*Lawrence O Gostin, John T Monahan, Mary C DeBartolo, Richard Horton}

O'Neill Institute for National and Global Health Law, Georgetown University Law Center, Washington, DC 20001, USA (LOG, MCD); Georgetown University, Washington, DC, USA (JTM); and The Lancet, London, UK (RH)

gostin@law.georgetown.edu

We declare no competing interests. The members of the Lancet- $0^{\prime}$ Neill Institute Georgetown University Commission on Global Health and the Law are: Lawrence Gostin (Co-Chair), John Monahan (Co-Chair), Ala Alwan,

Agnes Binagwaho, Gian Luca Burci, Luisa Cabal, Katherine DeLand, Tim Evans, David Fidler, Eric Goosby, Sara Hossain, Howard Koh, Gorik Ooms, Peter Piot, Mirta Roses Periago, Rodrigo Uprimny, and Alicia Yamin

1 WHO. International Health Regulations (2005), second edition. Geneva: World Health Organization, 2008.

2 WHO. Ebola response roadmap. Geneva: World Health Organization, 2014.

3 Gostin LO. Ebola: towards an International Health Systems Fund. Lancet 2014; 384: e49-e51

4 WHO. WHO report on the global tobacco epidemic, 2013: enforcing bans on tobacco advertising, promotion and sponsorship. Geneva: World Health Organization, 2013.

5 Philip Morris Brands Sàrl, Philip Morris Products S.A. and Abal Hermanos S.A. v. Oriental Republic of Uruguay, ICSID Case No. ARB/10/7 (formerly FTR Holding SA, Philip Morris Products S.A. and Abal Hermanos S.A. v. Oriental Republic of Uruguay). Victoria: Investment Treaty Arbitration, 2010. Italaw 2015. http://www.italaw.com/cases/460 (accessed April 14, 2015)

6 WTO. Procedural Agreement between Australia and Ukraine, Honduras, the Dominican Republic, Cuba and Indonesia. Australia-Certain Measures Concerning Trademarks and Other Plain Packaging Requirements Applicable to Tobacco Products and Packaging (WT/DS434/12). Australia-Certain Measures Concerning Trademarks, Geographical Indications and Other Plain Packaging Requirements Applicable to Tobacco Products and Packaging (WT/DS435/17, WT/DS441/16, WT/DS458/15, WT/DS467/16). April 24, 2014. https://docs.wto.org/dol2fe/Pages/FE_Search/FE_S_S009-DP.aspx?la nguage $=E \&$ CatalogueldList $=124313 \&$ CurrentCatalogueldIndex $=0 \&$ FullText Search $=($ accessed April 16, 2015) 